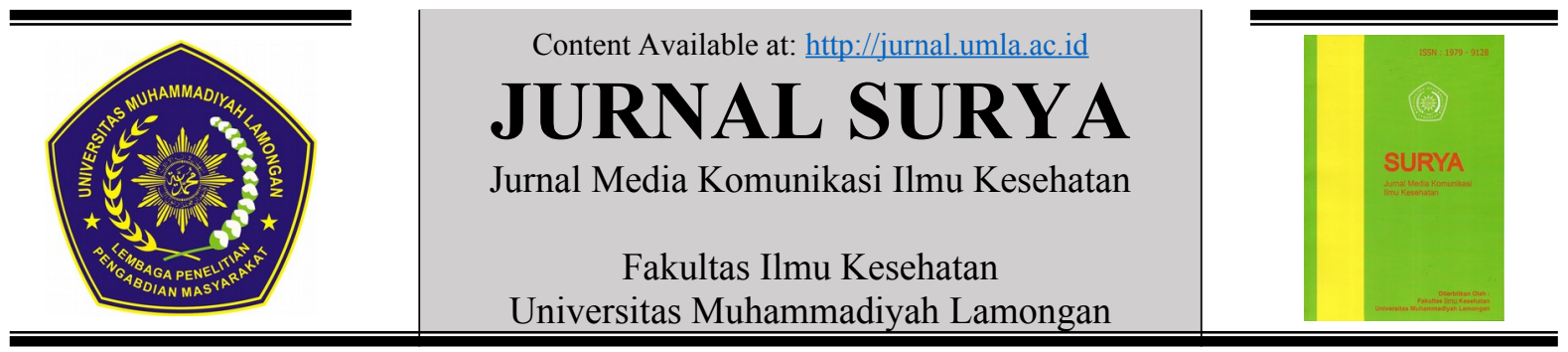

\title{
Kajian Faktor Pemberian ASI Eksklusif, Riwayat Berat Badan Lahir dan Ekonomi Keluarga terhadap Kejadian Balita Stunting
}

Nurul Aini

Program Studi Ilmu Keperawatan FIKES Universitas Muhammadiyah Malang

\section{ARTIKEL INFO}

\section{Article History:}

SM at 28-11-2019

$R V$ at $02-12-2019$

$P B$ at 24-12-2019

\section{Kata Kunci:}

Faktor penyebab

Balita

Stunting

\section{Korespondensi Penulis:}

\begin{abstract}
ABSTRAK
Background: Salah satu bentuk kegagalan pertumbuhan secara fisik pada anak adalah kondisi "stunting". Stunting adalah bentuk gangguan pertumbuhan yang ditandai anak memiliki tinggi badan yang kurang sesuai dengan usianya, yang disebabkan oleh kekurangan gizi secara kronis sejak masa kehamilan. Kejadian balita Stunting patut diwaspadai, karena bahaya stunting dapat menyebabkan generasi yang tidak cerdas dan berpenyakitan. WHO menetapkan batas toleransi stunting (bertubuh pendek) maksimal 20 persen atau seperlima dari jumlah keseluruhan balita. Sementara, di Indonesia tercatat 7,8 juta dari 23 juta balita adalah penderita stunting atau sekitar 35,6 persen. Sebanyak 18,5 persen kategori sangat pendek dan 17,1 persen kategori pendek. Pada tahun 2018, di Jawa timur terdapat 2,1 persen balita terkena stunting dari total jumlah balita yang ada. Para pakar menjelaskan bahwa penyebab utama stunting adalah karena masalah kekurangan gizi kronis sejak masa kehamilan. Penelitian ini dilakukan pada kelompok masyarakat yang memiliki Balita dengan rentang usia 2 sampai 5 tahun di wilayah kerja puskesmas yang ada di Kota Batu.
\end{abstract}

Objectives: Tujuan penelitian ini adalah mengkaji beberapa factor yang mempengaruhi terjadinya kondisi Stunting pada Balita.

Design: Desain penelitian menggunakan metode probability sampling sebagai teknik pengumpulan data, dengan mengambil sample sejumlah 106 responden.

Results: Hasil analisis data penelitian dengan menggunakan uji regresi liner didapatkan faktor Ekonomi (X3) dengan nilai signifikansi $0,002<0,005$ dan $\mathrm{t}$ hitung $3.182>\mathrm{t}$ tabel 2,262, sehingga dapat disimpulkan bahwa X3 berpengaruh terhadap Y.

Conclusions: Dengan demikian dapat disimpulkan bahwa faktor ekonomi menjadi faktor dominan diantara faktorfaktor penyebab stunting. 


\section{PENDAHULUAN}

Enam tahun pertama kehidupan anakanak adalah masa yang sangat penting. Pada masa ini terjadi pertumbuhan dan perkembangan anak yang akan berpengaruh secara signifikan pada tahap kehidupan selanjutnya (Soetjiningsih, 2015). Fokus perhatian utama pada masa tersebut, tidak hanya tertuju kepada pesatnya pertumbuhan secara fisik, tetapi juga perkembangan secara psikologis dan spiritual. Namun perlu digarisbawahi bahwa bagus tidaknya pertumbuhan secara fisik, sangat menentukan keberhasilan perkembangan yang menyertainya.

Salah satu bentuk kegagalan pertumbuhan secara fisik pada anak adalah kondisi "stunting". Stunting adalah bentuk gangguan pertumbuhan yang ditandai anak memiliki tinggi badan yang kurang sesuai dengan usianya, yang disebabkan oleh kekurangan gizi secara kronis sejak masa kehamilan. Kejadian balita Stunting patut diwaspadai, karena bahaya stunting dapat menyebabkan generasi yang tidak cerdas dan berpenyakitan. Dapat dibayangkan bagaimana jadinya Negara kita jika calon pemimpin dilahirkan dalam kondisi kurang gizi. Kondisi stunting dapat terdeteksi ketika anak berusia 2 tahun.

WHO menetapkan batas toleransi stunting (bertubuh pendek) maksimal 20 persen atau seperlima dari jumlah keseluruhan balita. Sementara, di Indonesia tercatat 7,8 juta dari 23 juta balita adalah penderita stunting atau sekitar 35,6 persen. Sebanyak 18,5 persen kategori sangat pendek dan 17,1 persen kategori pendek. Ini juga yang mengakibatkan WHO menetapkan Indonesia sebagai negara dengan status gizi buruk, (Republika, 2017). Pada tahun 2018, di Jawa timur terdapat 2,1 persen balita terkena stunting dari total jumlah balita yang ada. Kondisi tersebut hampir merata terjadi di semua wilayah, namun terdapat 11 daerah yang menjadi fokus perhatian, salah satunya adalah Malang Raya. Para pakar menjelaskan bahwa penyebab utama stunting adalah karena masalah kekurangan gizi kronis sejak masa kehamilan. Mulai dari ketidakmampuan mendapatkan makanan yang bergizi baik karena kurang pengetahuan dan informasi, gangguan lingkungan, sampai masalah kekurangan ekonomi dan masalah social budaya.

Hasil studi pendahuluan di Kota Batu didapatkan data bahwa sebagian balita penderita stunting diasuh oleh keluarga yang memiliki pola asuh kurang baik. Sehingga diduga keluarga tersebut memiliki pengetahuan yang kurang dan berakibat buruknya pola pengasuhan termasuk dalam hal pemenuhan gizi. Besarnya potensi alam dan SDM di Kota Batu seharusnya dapat memberi dampak terhadap turunnya angka kejadian stunting. Namun yang lebih penting adalah mencari akar masalah terlebih dahulu. Membuat peta masalah yang tepat bisa mempermudah bagaimana seharusnya Balita stunting bisa dicegah kejadiannya serta yang terlanjur menderita dapat ditangani secara tepat.

Berdasarkan fenomena diatas, peneliti bermaksud mengkaji faktor-faktor yang berpengaruh terhadap kejadian Balita Stunting, sehingga nantinya bisa didapatkan gambaran factor apa yang paling dominan. Hasil penelitian ini diharapkan bisa menjadi salah satu pijakan atau pertimbangan dalam penanganan masalah Balita Stunting.

\section{METODE}

Penelitian ini menggunakan desain studi observasional dengan dengan pendekatan cross sectional. Responden yang digunakan adalah orangtua yang memiliki Balita usia 2 sampai dengan 5 tahun baik yang dalam kondisi stunting maupun tidak stunting sejumlah 106 orang yang tinggal di wilayah kerja puskesmas seluruh Kota Batu Jawa Timur. Penelitian dilaksanakan mulai bulan Juni sampai dengan Oktober 2019 dengan menggunakan kuesioner sebagai instrument pengambilan data

Analisa data dalam penelitian ini meliputi analisa univariat, bivariat, dan multivariate. Analisa univariat digunakan untuk mengidentifikasi data demografi, yang mencakup usia responden, jenis kelamin, status ekonomi, status pemberian ASI eksklusif, dan riwayat berat badan lahir balita. Sedangkan analisa bivariate dengan menggunakan uji chi square digunakan untuk menganalisis adanya pengaruh ketiga variable. Adapun analisis multi variat 
digunakan untuk mengidentifikasi factor mana yang paling mempengaruhi terhadap kejadian Balita dengan Stunting.

\section{HASIL PENELITIAN}

Karakteristik responden meliputi usia anak, jenis kelamin anak, pendidikan orang tua, pekerjaan orang tua, serta pendapatan per bulan dari orang tua.

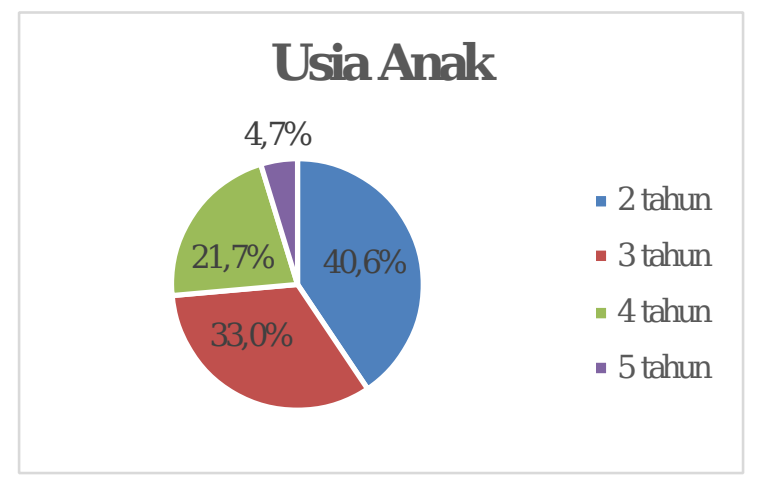

Sumber : kuesioner (2019)

Gambar 1. Karakteristik Responden berdasarkan Usia Anak

Karakteristik responden Berdasarkan usia anak didapatkan hasil orangtua dengan anak usia 2 tahun sebanyak $40,6 \%$, usia 3 tahun sebanyak $33,0 \%$, usia 4 tahun sebanyak $21,7 \%$, dan anak usia 5 tahun sebanyak $4,7 \%$.

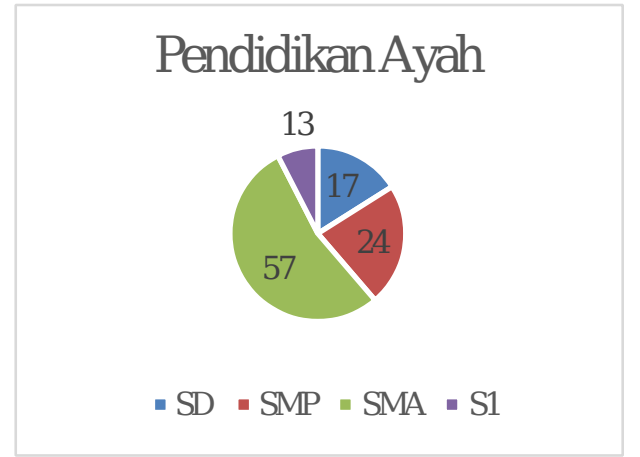

Sumber : kuesioner 2019

Gambar 2. Karakteristik Responden

Berdasarkan Tingkat Pendidikan

Berdasarkan pada gambar 3 di atas menunjukkan bahwa mayoritas Pendidikan orang tua anak adalah berpendidikan SMA dengan jumlah 57 ayah $(53,77 \%)$ dan $72 \mathrm{ibu}$ $(67,92)$.

\section{Pendapatan}

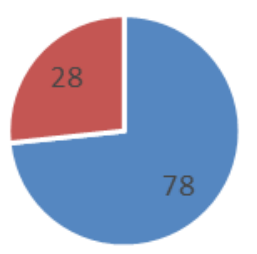

- $<$ UMR - >UMR

Sumber : kuesioner 2019

Gambar 3. Karakteristik Berdasarkan Pendapatan Orang Tua

Berdasarkan gambar 3 diatas didapatkan data bahwa mayoritas orang tua anak memiliki penghasilan yang berada di bawah ambang standar UMR yaitu sebanyak 78 orang tua $(73,58 \%)$.

\section{Status Pertumbuhan}

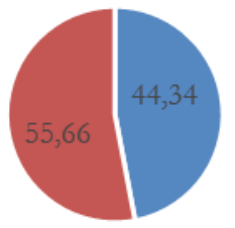

- Stunting - Tidak Stunting

Sumber : kuesioner 2019

Gambar 4. Distribusi Frekuensi Kejadian Stunting

Gambar 4 diatas menggambarkan data bahwa dari 106 responden, terdapat $44,34 \%$ responden yang memiliki Balita dengan Stunting, sedangkan $55,66 \%$ memiliki anak Balita yang tidak stunting. 
Tabel 1 Distribusi Frekuensi Faktor Asupan Karbohidrat yang Mempengaruhi kejadian Stunting

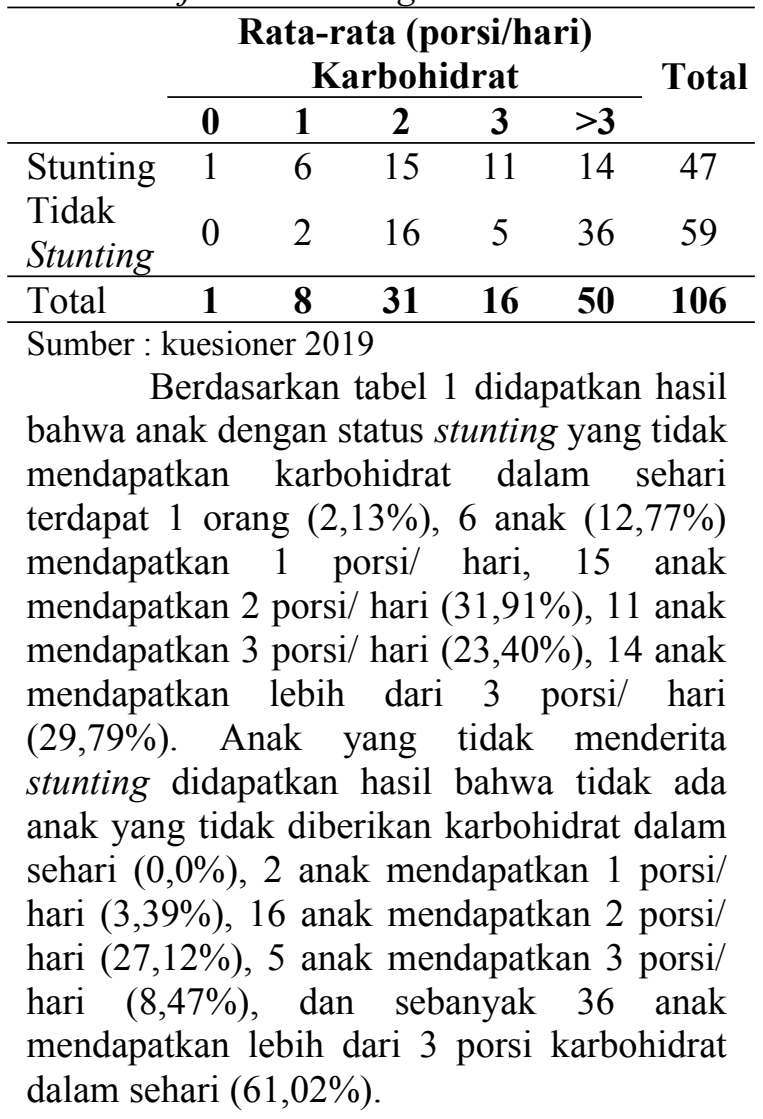

Tabel 2 Distribusi Frekuensi Faktor Asupan Protein yang Mempengaruhi kejadian Stunting

\begin{tabular}{|c|c|c|c|c|c|c|}
\hline & \multicolumn{5}{|c|}{$\begin{array}{c}\text { Rata-rata (porsi/hari) } \\
\text { Protein }\end{array}$} & \multirow[t]{2}{*}{ Total } \\
\hline & $\mathbf{0}$ & 1 & 2 & 3 & $>\mathbf{3}$ & \\
\hline Stunting & 14 & 11 & 12 & 8 & 2 & 47 \\
\hline $\begin{array}{l}\text { Tidak } \\
\text { Stunting }\end{array}$ & 0 & 31 & 15 & 9 & 4 & 59 \\
\hline Total & 14 & 42 & 21 & 17 & 6 & 106 \\
\hline $\begin{array}{l}\text { Sumber: } \\
\text { diatas m } \\
\text { menderit } \\
14 \text { anak } \\
(29,79 \% \\
(23,40 \% \\
(25,53 \% \\
(17,02 \% \\
\text { porsi su } \\
\text { Anak } \\
\text { didapatk } \\
\text { tidak dib } \\
(0,0 \%),\end{array}$ & $\begin{array}{l}, 11 \\
12 \\
, 8 \\
\text { tida } \\
\text { nber } \\
\text { nang }\end{array}$ & $\begin{array}{l}\text { men } \\
\text { nak } \\
\text { nak } \\
\text { nak } \\
2 \text { an }\end{array}$ & $\begin{array}{l}9 \\
\text { ein to } \\
\text { bahw } \\
\text { dapa } \\
\text { apatk } \\
\text { diber } \\
\text { diber } \\
\text { diber } \\
\text { k dib } \\
\text { dal } \\
\text { m }\end{array}$ & $\begin{array}{l}n \text { su } \\
\text { aan } \\
\text { xan } 2 \\
\text { an } 3 \\
\text { rikan } \\
\text { n seh } \\
\text { nderi }\end{array}$ & da & $\begin{array}{l}\text { ble } 2 \\
\text { yang } \\
\text { anyak } \\
\text { rotein } \\
\text { hari } \\
\text { hari } \\
\text { hari } \\
\text { tari } 3 \\
26 \% \text { ). } \\
\text { inting } \\
\text { yang }\end{array}$ \\
\hline
\end{tabular}

(52,54\%), 15 anak mendapatkan 2 porsi/ hari $(25,42 \%), 9$ anak mendapatkan 3 porsi/ hari $(15,25 \%)$, dan hanya 4 anak yang mendapatkan lebih dari 3 porsi/ hari $(6,78 \%)$.

\begin{tabular}{|c|c|c|c|c|c|c|}
\hline & $a n$ & & $\begin{array}{l}\text { ekue } \\
\text { ang } \\
\text { ting }\end{array}$ & & & $\begin{array}{l}\text { upan } \\
\text { Iruhi }\end{array}$ \\
\hline & \multicolumn{5}{|c|}{$\begin{array}{c}\text { Rata-rata (porsi/hari) } \\
\text { Vitamin }\end{array}$} & \multirow[t]{2}{*}{ Total } \\
\hline & 0 & 1 & 2 & 3 & $>3$ & \\
\hline Stunting & 19 & 14 & 7 & & 3 & 47 \\
\hline $\begin{array}{l}\text { Tidak } \\
\text { Stunting }\end{array}$ & 8 & 35 & 9 & 4 & 3 & 59 \\
\hline Total & 27 & 49 & 16 & 8 & 6 & 106 \\
\hline
\end{tabular}

Sumber : kuesioner 2019

Tergambar pada table 3 asupan protein bahwa pada anak yang menderita stunting didapatkan hasil sebanyak 19 anak tidak mendapatkan sumber vitamin $(40,43 \%)$, 14 anak diberikaan 1 porsi/ hari $(29,79 \%), 7$ anak diberikan 2 porsi/ hari $(14,89 \%), 4$ anak diberikan 3 porsi/ hari $(8,51 \%)$, dan 3 anak diberikan lebih dari 3 porsi sumber vitamin dalam sehari $(6,38 \%)$. Anak yang tidak menderita stunting didapatkan hasil bahwa mayoritas anak mendapatkan sumber vitamin yang diberikan sebanyak 1 porsi/ hari adalah sebanyak 35 anak (59,32\%), dan hanya 8 anak yang tidak diberikan sumber vitamin $(13,56 \%)$.

\section{Tabel 4 Distribusi Frekuensi Faktor Asupan Mineral yang Mempengaruhi} kejadian Stunting

\begin{tabular}{lcccccc}
\hline & \multicolumn{5}{c}{ Rata-rata (porsi/hari) } \\
& \multicolumn{7}{c}{ Mineral } & \multicolumn{1}{c}{ Total } \\
& $\mathbf{0}$ & $\mathbf{1}$ & $\mathbf{2}$ & $\mathbf{3}$ & $>\mathbf{3}$ & \\
\hline Stunting & 5 & 19 & 6 & 10 & 7 & 47 \\
Tidak & 5 & 34 & 13 & 5 & 2 & 59 \\
Stunting & $\mathbf{1 0}$ & $\mathbf{5 3}$ & $\mathbf{1 9}$ & $\mathbf{1 5}$ & $\mathbf{9}$ & $\mathbf{1 0 6}$ \\
\hline Total & $\mathbf{1 0}$
\end{tabular}

Sumber : kuesioner 2019

Berdasarkan tabel 5.4 menunjukan bahwa sebanyak 5 anak yang tidak diberikan sumber mineral dalam sehari $(10,64 \%), 19$ anak mendapatkan 1 porsi sumber mineral/ hari $(40,43 \%), 6$ anak mendapatkan 2 porsi/hari (12,77\%), 10 anak mendapatkan 3 porsi/ hari $(21,28 \%)$, dan sebanyak 7 anak mendapatkan lebih dari 3 porsi/ hari $(14,89 \%)$. Anak yang tidak menderita stunting mayoritas mendapatkan sumber 
mineral minimal 1 porsi/ hari sebanyak 34 anak (57,63\%).

Tabel 5 Distribusi Frekuensi Faktor Riwayat Berat Badan Lahir (BBL) yang mempengaruhi kejadian Stunting

\begin{tabular}{|c|c|c|c|}
\hline & \multicolumn{2}{|c|}{ BBL } & \multirow{2}{*}{ Total } \\
\hline & $<2,5 \mathrm{Kg}$ & $>2,5 \mathrm{Kg}$ & \\
\hline Stunting & 16 & 31 & 47 \\
\hline $\begin{array}{l}\text { Tidak } \\
\text { Stunting }\end{array}$ & 4 & 55 & 59 \\
\hline Total & 20 & 86 & 106 \\
\hline $\begin{array}{l}\text { Sumber : } \\
\text { B } \\
\text { bahwa p } \\
\text { didapatka } \\
\text { berat bad } \\
31 \text { anak } \\
2,5 \mathrm{~kg}(6 \\
\text { mengalan } \\
\text { mayoritas } \\
\text { dari } 2,5 \mathrm{k} \\
\text { dan hany } \\
\text { badan lah }\end{array}$ & $\begin{array}{l}\text { sioner } 201 \\
\text { lasarkan } \\
\text { anak } \\
\text { sebanyak } \\
\text { kurang } \\
\text { ir dengai } \\
6 \% \text { ). An } \\
\text { stuntin } \\
\text { nemiliki } \\
\text { aitu seba } \\
\text { anak ya } \\
\text { curang da }\end{array}$ & $\begin{array}{l}\text { gel } 5 \\
\text { gan stat } \\
\text { anak la } \\
2,5 \mathrm{~kg}(3 \\
\text { rat badar } \\
\text { dengan } \\
\text { didapat } \\
\text { t badan } \\
\mathrm{k} 55 \text { ana } \\
\text { yang me } \\
5 \mathrm{~kg}(6,7\end{array}$ & $\begin{array}{l}\text { mbarkan } \\
\text { stunting } \\
\text { dengan } \\
4 \% \text { ) dan } \\
\text { ebih dari } \\
\text { us tidak } \\
\text { hir hebih } \\
\begin{array}{l}93,22 \%), \\
\text { iki berat } \\
\text { ). }\end{array}\end{array}$ \\
\hline
\end{tabular}

Tabel 6 Status riwayat Pemberian Asi Ekslusif

\begin{tabular}{lccc}
\hline & \multicolumn{2}{c}{ Pemberian ASI } & \multirow{2}{*}{ Total } \\
\cline { 2 - 3 } & Eksklusif & Tidak & \\
\hline Stunting & 26 & 21 & 47 \\
Tidak & 59 & 0 & 59 \\
Stunting & & $\mathbf{2 1}$ & $\mathbf{1 0 6}$ \\
\hline Total & $\mathbf{8 5}$ & &
\end{tabular}

Sumber : kuesioner 2019

Berdasarkan tabel 6 diatas terlihat data bahwa anak yang menderita stunting didapatkan sebanyak 26 dari 47 anak yang mendapatkan ASI eksklusif (55,32\%) sedangkan pada anak yang tidak mengalami stunting didapatkan hasil bahwa seluruh anak dari total 59 anak mendapatkan ASI eksklusif $(100 \%)$.

Tabel 7 Status Ekonomi Keluarga Balita

\begin{tabular}{lccc}
\hline & \multicolumn{2}{c}{ Perekonomian } & Total \\
\cline { 2 - 3 } & <UMR & >UMR & \\
\hline Stunting & 17 & 30 & 47 \\
Tidak & 11 & 48 & 59 \\
Stunting & $\mathbf{2 8}$ & $\mathbf{7 8}$ & $\mathbf{1 0 0}$ \\
\hline Total & $\mathbf{2 8}$
\end{tabular}

Sumber : kuesioner 2019
Berdasarkkan tabel 7 di atas menunjukkan fakta bahwa, baik orang tua dari anak dengan status stunting maupun tidak sama-sama memiliki pendapatan di bawah UMR. 30 orang tua yang memiliki anak dengan stunting memiliki pendapata di bawah UMR $(63,83 \%)$ dan 48 orang tua dari anak yang tidak mengalami stunting $(81,36 \%)$.

\section{PEMBahasaN}

1. Gambaran Faktor Berat Badan Lahir dengan Penyebab Terjadinya Stunting

Melalui uji analisis statistic, didapatkan hasil nilai probabilitas $<0,05$, yaiti 0,01, hal ini bermakna bahwa H1 diterima, yang artinya ada hubungan antara Berat Badan Lahir (BBL) dengan kejadian stunting. Hal ini bisa terjadi karena anak dengan riwayat berat badan lahir rendah sangat berpotensi mengalami keterlambatan dalam pertumbuhan dan perkembangan. Dalam penelitian ini, data BBLR tidak spesifik menyatakan apakah BBLR dengan kehamilan cukup bulan atau kurang bulan. Besar kemungkinan anak-anak yang lahir dengan BBLR kurang bulan, akan mengalami keterlambatan dalam hal kenaikan Berat Badan. Apalagi jika tidak ditunjang dengan ketrampilan orangtua dalam pemenuhan kebutuhan nutrisi yang spesifik.

Hasil penelitian ini juga diperkuat oleh penelitian yang dilakukan oleh Vonaesch, et al (2017) yang memarkan bahwa anak-anak yang lahir dengan berat badan lahir rendah mengalami risiko terhambatnya pertumbuhan sebesar $20 \%$, serta anak-anak dengan berat badan lahir rendah dalam penelitian ini berisiko lebih tinggi untuk mengalami stunting. Penelitian ini menunjukkan bahwa anak yang dilahirkan dengan berat badan lahir rendah dilahirkan dengan cadangan nutrisi, vitamin A, seng, dan zat besi yang rendah. Responden yang digunakan dalam penelitian ini adalah balita yang berusia 2 sampai dengan 5 tahun, dengan jumlah usia terbanyak adalah balita dengan usia 3 tahun. Usia balita merupakan usia yang paling rentan terhadap kejadian stunting. Hal ini didukung oleh penelitian dari Keino et al (2014) yang menyatakan bahwa pengerdilan pada masa kanak-kanak ditemukan semakin meningkat dengan 
bertambahnya usia hingga usia lebih dari 24 bulan. Kecenderungan serupa telah dilaporkan dalam sejumlah studi sebelumnya dalam pengembangan di berbagai negara.

\section{Gambaran Faktor Pengaruh Pemberian ASI Eksklusif pada Balita Terhadap Penyebab Terjadinya Stunting.}

Pada tahapan ini uji analisis statistik mendapatkan hasil $(\mathrm{p}=0,000)$ yang artinya ada pengaruh riwayat pemberian ASI Eksklusif dengan kejadian stunting pada anak balita. Hal ini sangat jelas, mengingat kandungan gizi ASI yang luarbiasa. ASI ibu mengandung banyak nutrien yang berfungsi untuk membangun membangun serta menyediakan energi bagi kebutuhan bayi. Dengan terpenuhinya nutiren yang baik, maka bayi dapat terhidar dari stunting. Hasil penelitian menunjukkan bahwa pada mayoritas anak dengan riwayat pemberian ASI ekslusif (56 \%) tidak mengalami kejadian stunting. Hal ini senada dengan hasil penelitian yang dilakukan oleh Fitri (2018) yang mendapatkan hasil bahwa anak yang mendapatkan ASI eksklusif mempunyai resiko lebih kecil untuk mengalami stunting (Fitri, 2018).

$$
\text { Penelitian yang dilakukan oleh }
$$

Ni'mah \& Nadhiroh (2015) juga menunjukkan hasil bahwa ada hubungan antara pemberian ASI eksklusif dengan kejadian stunting. Balita yang tidak mendapatkan ASI eksklusif ( 6 bulan pertama kehidupan) memiliki resiko 4 kali lebih tinggi terkena stunting jika dibandingkan balita yang mendapatkan ASI eksklusif. (K. Ni'mah \& Nadhiroh, 2015). Penelitian milik Aridiyah dkk (2015) juga menyatakan bahwa umur pertama kali pemberian ASI eksklusif mempengaruhi tumbuh kembang dan kejadian stunting. Hasil penelitiannya juga menunjukkan data tentang balita yang tidak diberikan ASI eksklusif baik diwilayah perkotaan atau perdesaan memiliki kaitan dengan kejadian stunting (Aridiyah, 2015)

Penelian pendukung lainnya adalah penelitian yang dilakukan oleh Lertari, et al (2018) dimana hasil penelitiannya mengungkapkan bahwa terhadap hubungan yang signifikan antara pemberian ASI eksklusif terhadap kejadian stunting pada balita dengan rentang usia 24-59 bulan. Lebih banyak anak dengan status gizi normal yang menerima ASI eksklusif $\quad(86,7 \%)$ dibandingkan dengan balita yang mengalami stunting (56,7\%). Analisi bivariat pada penelitian Lestari (2014) menunjukkan bahwa pemberian ASI eksklusif adalah faktor pelindung terhadap kejadian stunting, dengan OR 0,201. Lebih lanjutnya, analisis multivariat mengungkapkan bahwa pemberian ASI secara eksklusif masih merupakan faktor pelindung terhadap stunting dengan OR 0,234 (95\% CI 0,061$0,894)$. Balita yang tidak mendapatkan ASI eksklusif memiliki risiko 5 kali lebih tinggi untuk mengalami stunting dibandingkan dengan balita yang mendapatkan ASI secara eksklusif.

\section{Gambaran Pengaruh Faktor ekonomi Keluarga Terhadap Penyebab Terjadinya Stunting}

Hasil penelitian ini menunjukan bahwa mayoritas orang tua balita memiliki pendapatan dibawah UMR yaitu sebanyak 78 orang tua baik pada balita dengan stunting dan tidak dengan stunting. Berdasarkan uji chi-square didapatkan nilai probablilitas < 0,05 , yang menyatakan adanya hubungan antara apendapatan orang tua dengan kejadian anak stunting. Pendapatan yang masih dibawah UMR dapat mengakibatkan ketidakcukupan dalam pemenuhan kebutuhan dalam rumah tangga, salah satunya adalah kebutuhan gizi. Hal ini diperkuat oleh penelitian yang dilakukan Berhe et al (2019), dimana faktor ekonomi adalah salah satu faktor yang dapat menyebabkan terjadinya masalah gizi sehingga mengakibatkan terjadinya stunting. Hal ini dikaitkan dengan banyak faktor seperti pengetahuan gizi, status sosial ekonomi keluarga termasuk kemiskinan, masalah budaya dalam masyarakat dan keyakinan yang ada di masyarakat, cara pengolahan makanan, serta diet.

\section{Gambaran Faktor Dominan yang berpengaruh terhadap terjadinya Stunting pada Balita.}

Melalui uji regresi linier berganda didapatkan faktor ASI eksklusif (X1), dengan nilai signifikansi $0,000<0,005$, dan uji $\mathrm{T}$ didapatkan hasil bawah t hitung -5.455 $<$ t tabel 2,262, sehingga dapat disimpulkan bahwa X1 tidak berpengaruh terhadap 
YFaktor riwayat BBL kelahiran (X2), dengan nilai signifikansi $0,520>0,05$, dan $\mathrm{t}$ hitung $0.645<\mathrm{t}$ tabel 2,262 , sehingga dapat disimpulkan bahwa X2 tidak berpengaruh terhadap Y. Faktor Ekonomi (X3) dengan nilai signifikansi $0,002<0,005$ dan t hitung $3.182>\mathrm{t}$ tabel 2,262, sehingga dapat disimpulkan bahwa X3 berpengaruh terhadap Y. Dari ketiga interpretasi tersebut maka dapat disimpulkan bahwa dalam penelitian ini didapatkan kesimpulan bahwa faktor ekonomi menjadi faktor dominan diantara faktor-faktor penyebab stunting lainnya. Adapun faktor ekonomi dinilai sebagai salah satu faktor yang dapat menyebabkan terjadinya masalah gizi yang memicu terjadinya stunting. Hal ini dapat dikaitkan dengan banyak faktor seperti pengetahuan gizi, status sosial ekonomi keluarga termasuk kemiskinan, masalah budaya, dan keyakinan yang ada di masyarakat, cara pengolahan makanan, serta diet (Berhe et al, 2019). Pernyataan ini sejalan dengan penelitian yang dilakukan oleh Nshimyiryo et al (2019) dimana mereka mendapatkan hasil penelitian bahwa anak-anak dengan orang tua yang memiliki tingkat sosio-ekonominya rendah cenderung kurang terpapar nutrisi yang adekuat yang mengarah pada kejadian stunting. Menurut Kumar et al (2015) kemampuan sebuah keluarga untuk mencukupi kebutuhan sehari-hari seperti kebutuhan makanan akan dipengaruhi oleh tingkat pendapatan keluarga. Keluarga yang memiliki pendapatan yang relatif rendah akan mengalami kesulitan untuk mencukupi kebutuhan makanan. Pada umumnya jika pendapatan tinggi, jumlah dan jenis makanan akan cenderung adekuat, akan tetapi mutu makanan tidak selalu membaik. Hal ini disebabkan oleh karena peningkatan pendapatan yang diperoleh tidak digunakan untuk membeli pangan atau bahan makanan yang bergizi tinggi. Penelitian lain yang mendukung temuan dalam penelitian ini yaitu penelitian yang dilakukan oleh Kamal (2011), yang memaparkan bahwa keluarga dengan penghasilan yang rendah atau miskin memiliki keterbatasan untuk memenuhi berbagai sumber kebutuhan makanan. Sehingga tidak mampu untuk menyediakan makanan bergizi dan seimbang bagi anakanak mereka ketika dalam masa pertumbihan. Hal tersebut menjadi risiko yang lebih tinggi untuk kejadian stunting. Hubungan antara faktor ekonomi dengan kekurangan gizi merupakan manifestasi dari pola perkembangan somatik anak yang hidup dalam kondisi yang lebih buruk dengan asupan makanan yang tidak adekuat, serta paparan yang lebih besar seperi infeksi, dan kurangnya akses fasilitas kesehatan dasar turut berpengaruh. Temuan ini konsisten dengan studi sebelumnya yang dilakukan negara berkembang lainnya dan memaparkan bukti lebih lanjut bahwa status ekonomi rumah tangga merupakan faktor terjadinya stunting.

\section{KESIMPULAN}

Penelitian ini menyampaikan bahwa dari kajian factor Berat Badan Lahir (BBL), riwayat ASI eksklusif dan Faktor ekonomi keluarga sama-sama memberi kontribusi dalam mencetuskan kejadian Balita Stunting. Namun yang menjadi factor dominan dalam penelitian ini adalah factor ekonomi keluarga.

\section{DAFTAR PUSTAKA}

Aridiyah, F., Rohmawati, N., dan Ririanty, M. 2015. Faktor-faktor yang Mempengaruhi Kejadian Stunting pada Anak Balita di Wilayah Pedesaan dan Perkotaan. Jurnal Pustaka Kesehatan. 3(1) : 163-170.

Berhe, K., Seid, O., Yemana, G., Et Al. (2019). Risk Factors Of Stunting (Chronic Undernutrition) Of Children Aged 6 To 24 Months In Mekelle City, Tigray Region, North Ethiopia: An Unmatched Case-Control Study. PLOS,

Https://doi.org/10.1371/journal.pone. $\underline{0217736}$

Fitri L. Hubungan BBLR dan ASI eksklusif dengan kejadian stunting di Puskesmas Lima Puluh Pekanbaru. Padang: Jurnal Endurance; 2018, 3 (1); 131-137.

Kamal, M. (2011). Socio-economic Determinants of Severe and Moderate Stunting among Under-Five Children 
of Rural Bangladesh. Mal J Nutr 17(1): 105 - 118, 2011 Determinants of Severe \& Mod.

Keino, S., Plasqui, G., \& Ettyang G, van den Borne B. (2014). Determinants of stunting and overweight among young children and adolescents in sub-Saharan Africa. Food Nutr Bull; 35(2):167-78. https:// doi.org/10.1177/15648265140350020 3 PMID: 25076764

Kumar A, Kumari D, Singh A (2015). Increasing Socioeconomic Inequality In Childhood Undernutrition In Urban India: Trends Between 1992-93, 1998- 99 And 2005-06. Health Policy And Planning, 30(8): 1003-1016. Doi: 10.1093/Heapol/Czu104

Lertari, E.D., Hasanah, F., \& Nugroho, N.A. (2018). Correlation between nonexclusive breastfeeding and low birth weight to stunting in children. Paediatrica Indonesiana; Vol.58, No.3(2018). p. 123-7; doi: http://dx.doi.org/10.14238/pi58.3.201 $\underline{8.123-7}$

Lestari, W., Margawati, A., \& Rahfiludin, Zen. (2014). Faktor risiko stunting pada anak umur 6-24 bulan di kecamatan Penanggalan kota Subulussalam provinsi Aceh. Vol. 3, No. 1.

Ni'mah K, Nadhiroh SR. Faktor yang berhubungan dengan kejadian stunting balita. Media Gizi Indonesia. 2015; Vol. 10, No. 1 Januari-Juni.

Nshimyiryo, a., Gauthier, b.h., Mutaganzwa, c., et al (2019). Risk factors for stunting among children under five years: a cross-sectional populationbased study in Rwanda using the 2015 Demographic and Health Survey. BMC Public Health, 19:175 https://doi.org/10.1186/s12889-019$\underline{6504-\mathrm{Z}}$

Republika. 2017. WHO: 7,8 Juta Balita di Indonesia Penderita Stunting
Diakses tanggal 20 Agustus 2019 dari https://www.republika.co.id/berita/n asional/umum/18/01/24/

Soetjiningsih. 2014. Tumbuh Kembang Anak. Jakarta: Penerbit Buku Kedokteran EGC.

Vonaesch, et al. (2017). Factors associated with stunting in healthy children aged 5 years and less living in Bangui (RCA). PLoS ONE 12(8): e0182363.https://doi.org/10.1371/jour nal.pone. 0182363 